\title{
Fermentative Gram Negative Bacillus
}

National Cancer Institute

\section{Source}

National Cancer Institute. Fermentative Gram Negative Bacillus. NCI Thesaurus. Code C86395.

Any rod shaped, anaerobic bacteria that can convert carbohydrates into acids and alcohols and has a cell wall contains low levels of peptidoglycan and stains pink with the Gram staining technique. 